\title{
COMPLEX-VALUED STATISTICAL LEARNING FOR INSPECTING YOUTH LABOUR FORCE PARTICIPATION IN SERBIA
}

\author{
Bulent TUTMEZ ${ }^{1}$, Edit TEREK ${ }^{2}$ \\ ${ }^{1}$ Inonu University, School of Engineering, Malatya 44210, Turkey \\ E-mail: bulent.tutmez@inonu.edu.tr \\ ${ }^{2}$ University of Novi Sad, Technical faculty ”Mihajlo Pupin”, 23000 Zrenjanin, Đure Đakovića bb, \\ Republic of Serbia
}

UDC: 331.5-053.6:519.23(497.11)

Original Scientific Paper

Paper received: 18.04.2020,; Paper accepted: 11.05.2020.

\begin{abstract}
Youth employment in labour force has a critical importance in socio-economic planning. It is expected that the use of dynamic and able-bodied work force can increase the quality of the industrial products and it is also necessary to strengthen the economy. More importantly, the contribution to labour force has a crucial importance for public welfare. At this stage, since the role of young women in the total labour force is not considered sufficiently, this study concentrates on the determination of the relative effect of women labour force. For this purpose, first the youth employment is considered as a complex quantity; along with the real component (young men), the contribution of young women is treated as the imaginary component. By using the data derived from 20 different domains (sectors), the problem is stated as a complex value problem and a measurement uncertainty analysis is utilized. The measurement uncertainty of the complex quantity (employment) is expressed by a region in the complex plane. Finally, a confidence ellipse at $\mathbf{9 5 \%}$ confidence level is produced. The phase diagrams produced by statistical learning have provided some abnormalities and also potentials.
\end{abstract}

Keywords: Labour force; Complex number; Youth employment; Measurement uncertainty.

\section{INTRODUCTION}

It is a general view that when young people begin realizing their aspirations, they assume their economic independence and find their place in society. On the other hand, some unfavourable situations have influence on the vulnerability of young people such as higher unemployment, lower quality of jobs and greater labour market inequalities among different groups of young people, (Marjanovic, 2016). Providing employment equality has critical importance for people to realize their capacity, for the economy to use the skills and productivity of the workforce in an effective manner. In addition, this effort increases the social cohesion, (Matsumo, \& Elder, 2010). From a general perspective, employment equality received broad acceptance to the accomplishment of gender equality, (Ara, 2019; Gevrek, \& Seiberlich, 2011). In spite of the lengthy commitment to gender balance in employment, the achievement of real balance in the workplace is still one of the main objectives of both the European Union (Boll et al., 2016; Cerciello, 2019) and its member state Serbia, (Dokmanovic, 2016).

On the other hand, unemployment brings problems both of social and individual sense. First of all, unemployed resources (in this case labour force) indicate that production is less than potentially possible. In addition, there is a lack of utilization of knowledge, skills and other different abilities of the unemployed, (Petrovic et al., 2019). At the same time, unemployed persons face a number of personal problems: social exclusion, lack of opportunities, feeling of dependence and lower value, loss of self-confidence and trust in society.

Unemployment also represents one of the main problems of Serbia, in economic, social and developmental sense. A special problem is unemployment among young people, (Ćoćkalo et 
al., 2017). The unemployment rate for the population aged 15 and over is $11.3 \%$, while the unemployment rate among young people (15-24 years) is $25.3 \%$ (of the total active population of young people) (Statistical Office of the Republic of Serbia, the third quarter of 2018). It should be noted here that more and more young people from Serbia are leaving the country to work and live in other countries, which makes these parameters more favourable in comparison to the real situation. According to Ostojić and Petrović (2018), small and medium enterprises in Serbia are faced with numerous problems, such as low productivity and very small exports. Thus, SMEs in Serbia are based on the domestic market, where there is no high purchasing power of customers, and there comes to fall in demand, as well as the establishment of an insufficiently stimulating business environment and grey economy, (Paunović, 2017).

In such conditions there is a clear fear of starting an entrepreneurial venture, and so there comes to missing out of many business and entrepreneurial opportunities. Besides this, (Collet, \& Legros, 2016) it is underlined that women's decisions to go to work are characterized by significant state of dependence, unobserved heterogeneity and negative serial correlation in the transitory error component. Also, if a woman has young children in her household it reduces her labour participation.

As one of the important parameters of welfare and social security, the labour force participation was considered primarily in a parametric or semiparametric framework in applied economics, (Martins, 2001). Alternatively, nonparametric econometrical methods such as density estimation were discussed to understand the labour market behaviour, (Kumar, 2006). In practice, the role of a young woman in the total labour force cannot be appraised sufficiently due to uncertainties. Therefore, determining the roles of female labour forces in different workplaces and presenting the results in some attractive ways such as the combination of mathematics and social science, can lead to some reliable results. From this perspective, one of the methods to perform this analysis can be established using complex number theory in mathematics combining by measurement uncertainty analysis.
A covariance-matrix uncertainty description for $S$ parameter (used in Vector-Network-Analyzer: VNA) has been discussed by Lewandowski et al. (2010). The study exhibited that the statistical correlations between measurement uncertainties for different scattering-parameters are required when propagating scattering-parameter measurement uncertainties into uncertainties of other frequency-domain quantities, (Ridler, \& Salter, 2014). Thus, the statistical properties of the error mechanisms can be favourably captured in a covariance matrix. From this point, as a measured quantity, the extended uncertainty of employment was considered as a region in the complex plane surrounding the records (Hall, 2013).

The uncertainty of the labour force participation relies on the measurement uncertainty of the real and imaginary components as in complex numbers and in any correlation between those estimates. In this study, first the youth employment is conceived as a complex number placed in mathematics, (Andreescu, \& Andrica, 2014). In conjunction with the young men (real component), the contribution of young women has been included in the analysis as the imaginary component.

Making a reliable measurement uncertainty evaluation on the ground of a complex number structure and elliptical uncertainty analysis can provide new horizons and potentials to explore the contributions of women and men to labour markets, (Tutmez et al., 2019). From this reference point, the problem has been formulated as a complex-valued quantity problem and by using the data set obtained from 20 main activity sectors (agriculture, mining, forestry and fishing, manufacture, education, etc.) in Serbia, the relative contributions of young women and young men to the youth Serbian labour system have been appraised by complex measurement uncertainty analysis. The results have been illustrated by some phase diagrams (confidence ellipses) at 95\% confidence level. The ellipses revealed some abnormalities and the possibilities to assess the relative contributions of young women in Serbia to the economic system.

In the next section, the fundamentals of the problem and mathematical tools are introduced. After that, a case study using the real data set will be presented. In the last section a brief evaluation with conclusions will be given. 


\section{PROBLEM STATEMENT}

The full integration of the educated female population of Serbia into the working areas directly related with the self-realization, contributing to economic growth and avoiding the risk of poverty in the next years is the set problem. Therefore, a multidirectional and interrelated process is discussed. Beyond the relationships between employees and employers, a differentiation between the genders in different weights is also recorded in the work life.

Young people in Serbia are not sufficiently stimulated for self-employment: there is a wish, but there are numerous obstacles such as: lack of initial financial resources, lack of entrepreneurial knowledge and experience, but also real ideas. In addition, there is no strong social support for entrepreneurial activities, as well as an adequate environment for encouraging entrepreneurship among young people. It is necessary to include all relevant institutions in these processes. It is positive that there is awareness of the need to improve the situation in this area. This is supported by the fact that at the very beginning of the SME Development Strategy and Action Plan 2015-2020 (RSME, 2015) it is stated that the development of SMEs is "of vital importance for the recovery and development of Serbian economy, increase of employment and the improvement of living standards of citizens".

Although many records can be provided on the employment in a country, investigating the relative contributions of women and men to labour markets based on the indicative sectors correspond a novelty. In this problem, both the quantity of interest and the variables comprise of some complexity and different level of uncertainties, (Perez, \& Zangl, 2019). To appraise the main indicators and to make reliable analyses, the complex social parameters including uncertainty should be considered in a mathematical-statistical framework and some projections from the current data should be made. As extension of the uncertain number approach to complex-valued problem, the complex measurement uncertainty framework can be used for this purpose.

\section{METHODOLOGY}

\section{Complex numbers}

In mathematics, the set of complex numbers $\mathrm{C}$ is expressed as

$$
C=\{(x, y) \mathrm{I} x, y \in R\}
$$

A complex number $z$ is an ordered pair $(x, y)$ of real numbers $x$ and $y$ as follows

$$
z=(x, \mathrm{y})
$$

In eq. (2), $x$ and $y$ denote the real part and imaginary part of $z$, respectively. In practice, complex numbers are represented by (Andreescu, \& Andrica, 2014).

$$
z=x+i y \text {. }
$$

A complex number can be illustrated in a real/imaginary plane as in Figure 1. To represent the complex number, the same unit of lengths are chosen on both axes where the point $Z$ in the complex plane and $P$ denotes the magnitude of the complex number, (Kreyszig, 2011).

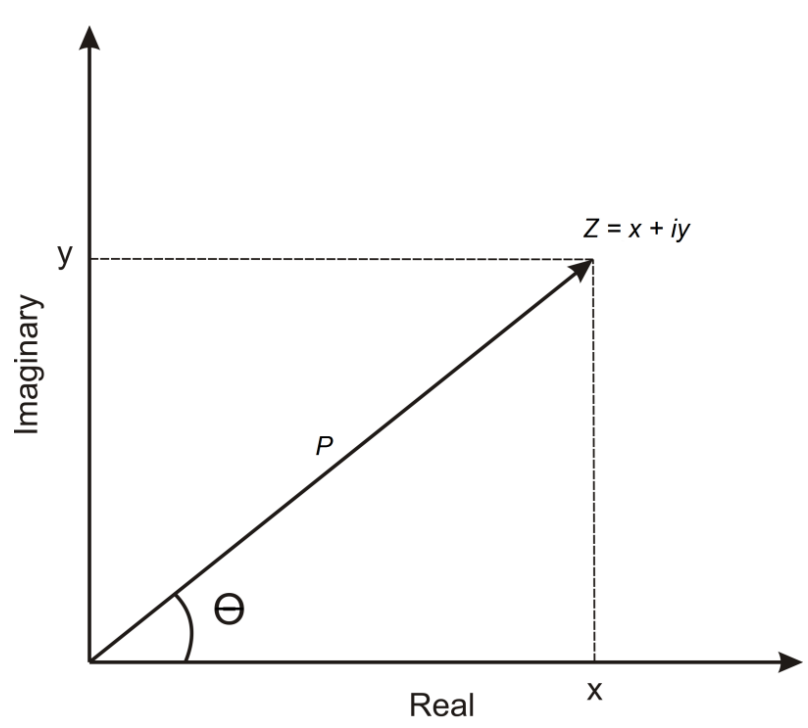

Figure 1: Complex number illustration.

In a polar form, besides $x y$ coordinates, we also use the polar coordinates $p$ and $\theta$ and complex number can be expressed as follows:

$$
Z=p(\cos \theta+i \sin \theta)
$$


In (4), $p$ is the modulus of $z$ and can be calculated by

$$
|z|=p=\sqrt{x^{2}+y^{2}}
$$

One of the critical parameters in complex number illustration is $\theta$ is called the argument of $\mathrm{Z}$ and provided as follows:

$$
\theta=\arg Z=\arctan \frac{y}{x}
$$

Because the labour force participation ratios have complexities based on many practical factors, the uncertainty of this complex phenomenon can be formulated by real and imaginary parts. Furthermore, the correlation between the real and imaginary components can be considered in the analyses.

\section{Propagation of uncertainty}

From a metrology perspective, measurement uncertainty (MU) characterizes the dispersion of the quantity values being attributed to a target variable (measurand). There is a variation due to some factors such as a model, instrument, recording and environmental conditions. In particular, random and systematic effects on the measurand are evaluated and quantified in measurement science. Thus, measurement models describe the relationships between target and indicator variables using some expressions, (Possolo, 2015).

The main motivation of a measurement is to numerically describe a process. For this identification, measurement is carried out to increase knowledge of the target variable. The traditional uncertainty evaluation utilizes standard uncertainty that is a statistical quantity equivalent to the standard variation of the error. In this way, measurement uncertainty represents a range of possible values that the error might assume for a measurement.

In a complex quantity-based measurement system, the functional relationship between multiple indicator variables and the measurand (target variable) can be expressed as follows:

$$
z=f\left(x_{1}, x_{2}, \ldots, x_{n}\right) .
$$

In Eq. (7), a standard uncertainty, $u\left(x_{c j}\right), c=1,2$; $j=1,2, \ldots l$ is connected with each of the real and imaginary components. Therefore, a measure of the contribution to uncertainty in measurand from the estimate $x_{j}$ is the component of uncertainty matrix. Based on the real and imaginary parts of the functional structure, the element of uncertainty matrices can be employed to appraise the following variance-covariance matrix connected with the measurand $z$ (Hall, 2013):

$$
V(z)=\left[\begin{array}{ll}
u^{2}(r) & u(r, i) \\
u(i, r) & u^{2}(i)
\end{array}\right]
$$

In Eq. (8), the terms $u^{2}(r)$ and $u^{2}(i)$ denote the variances of the real and imaginary parts, respectively. The terms $u(r, i)=u(i, r)$ represent the correlation (covariance) between the components of complex number. The system can be expressed using an ellipse. If the correlation equals to zero, the ellipse lines up with the real and imaginary axes and lengths of the ellipse axes are proportional to standard uncertainties of the complex number elements. If the correlation does not equal to zero, the ellipse is directed at the angle to the coordinate axes.

The uncertainty ellipse is graduated via a coverage factor $k_{2, p}^{2}$. This parameter depends on coverage level (probability) and the number of degrees of freedom $v$ as follows (Hall, 2012):

$$
k_{2, p}^{2}=\frac{2 v}{v-1} F_{2, v-1}(p) .
$$

In Eq. (9), for infinitive $v: k_{2, p}^{2}=\chi_{2, p}^{2}$ can be considered.

Measurement uncertainty analysis allows an objective and independent interpretation of the measurement results. In this way, the quality and proof of the adequacy of the measurement can be appraised. In the uncertainty analysis, the measurements are evaluated in a region at a userdefined confidence level. The uncertain complex number can be employed to provide full uncertainty propagation in multi-step processing of measurement, data (Hall, 2008). As reported in (Hall, 2016), the guidance on the evaluation of 
uncertainty (GUM) discussed a geometrical representation of uncertainty as an elliptical region in the complex plane, and showed how a multivariate form of Law of Propagation of Uncertainty (LPU) (JCGM, 2008) could be used to propagate uncertainty in a particular measurement. The main motivation of this analysis to expand measurement uncertainty of a complex quantity denoted in the complex plane as a region surrounding the measured value.

To show the parameters in geographical space, an ellipse is often utilized as a confidence region for the mean of a bivariate Gaussian distribution in multivariate statistics, (Garelli, \& Ferro, 2012). Since the residual errors influence not only real but also imaginary components, making an analysis in a complex number form by using an ellipse seems attractive. In Figure 2, an elliptical uncertainty region is depicted in connection with the complex number illustration where $k$ represents the coverage factor. The parameters in the ellipse such as length of the semi-minor $(a)$ and semi-major $(b)$ axes and the rotation angle $\Phi$ can be provided by the variance matrix of the complex number (Shoaib, 2017).

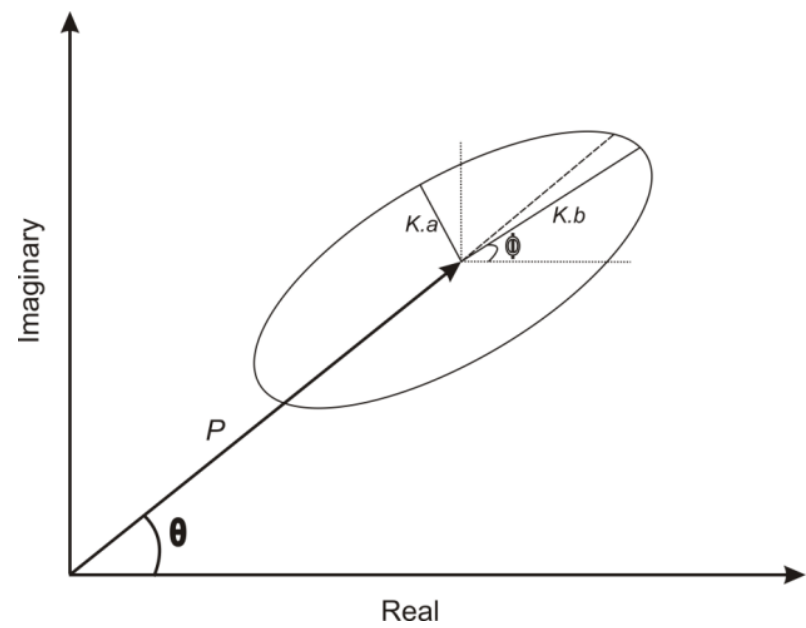

Figure 2: Uncertainty ellipse in complex number expression

\section{CASE STUDY}

\section{Data and structure identification}

The data set considered in this study has been provided in (Marjanovic, 2016). The set includes the number of the males and females in 20 main sectors such as agriculture, mining, manufacture etc. To explore the relationships between the genders based on the sectors, correlation plots given in Figure 3.
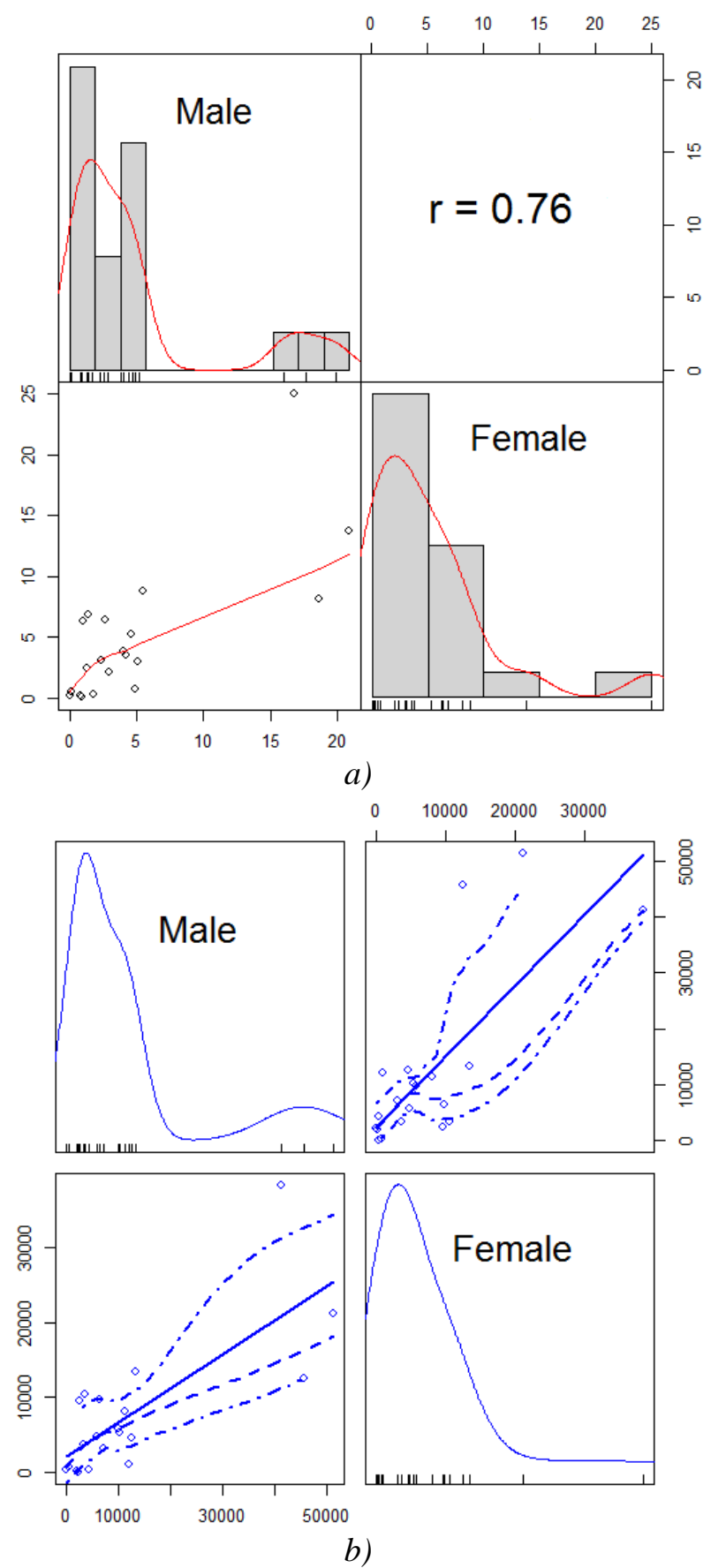

Figure 3: Relationships between contributions: a) Contribution ratio b) Number of employment.

In Figure 3a, based on contributions (\%) of each gender in own working domain, the variability is expressed by histograms and the potential nonlinear relationship is expressed by correlation coefficients as 0.76 . In right plot (Figure 3b), positive skewed distributions of the genders and the variations of the linear relationship between the gender labour forces is illustrated. Comparing with 
the males, the females in the sectors show smoothed densities. The relative contributions of the males have some fluctuations in terms of the sector types. It is important that the correlation between the genders in the small working sectors is better than in the big sectors.

In the first step the contribution of the genders (\%) has been calculated as follows:

$$
\begin{aligned}
C_{k_{m}} & =\frac{N_{k_{m}}}{N_{m}+N_{f}} \times 100, \\
C_{k_{f}} & =\frac{N_{k_{f}}}{N_{m}+N_{f}} \times 100 .
\end{aligned}
$$

$N_{m}$ and $N_{f}$ denote the number of males and females. The contribution in each sector $\left(C_{k_{m}}\right.$ and $C_{k_{f}}$ values) recorded is illustrated in Figure 4. As seen in Figure 4, the employment of males is dramatically greater than the employment of females. The exceptional sectors are education and health sectors.

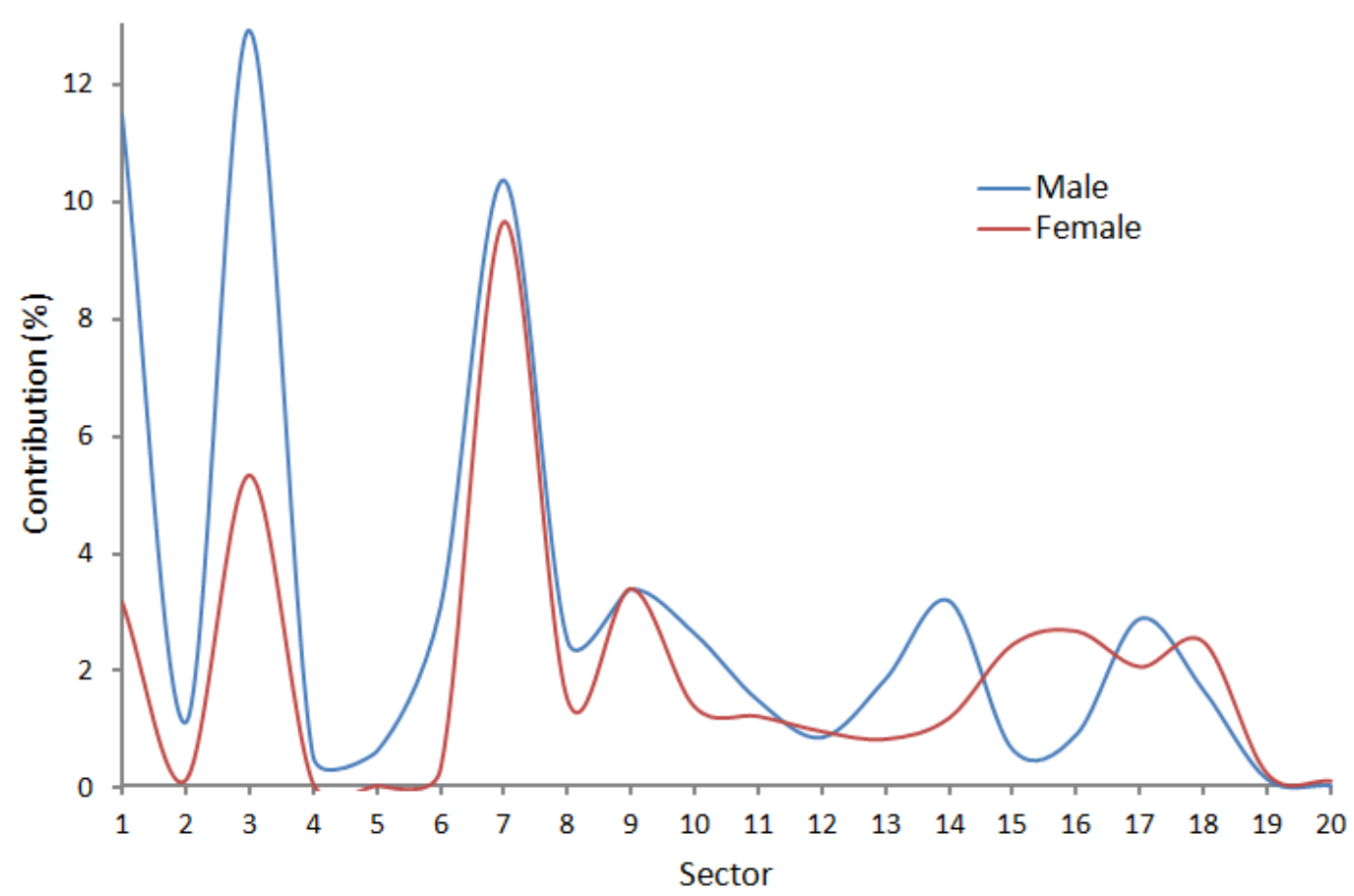

Figure 4: Contributions of genders in different sectors

\section{Complex number-based intelligent analysis}

To propagate the uncertainty of employment in the complex-valued quantity, the uncertainty matrix is a useful way of expressing. The discovering relationships between real part (male) and imaginary part (female) is the ground of the calculations. For this purpose, the variances of real and imaginary components, $\sigma_{r}, \sigma_{i}$ as well as the covariance $\sigma_{r i}=\sigma_{i r}$ should be provided. The variances correspond to the standard uncertainties in measurement uncertainty framework given in Eq. (8). Based on these parameters, the uncertainty of variance matrix of a complex number for gender $\left(V_{g}\right)$ can be expressed as follows, (Hall, 2016).

$$
V_{g}=\left[\begin{array}{ll}
\sigma_{r} & \sigma_{r i} \\
\sigma_{i r} & \sigma_{i}
\end{array}\right] .
$$

The uncertainty matrix not only captures the uncertainties of the scattering parameter measurements, but also the statistical correlations. Based on the structure in Eq. (11), the following uncertainty matrix has been provided using $C_{k_{m}}$ and $C_{k_{f}}$ values in Eq. (10): 


$$
V_{g}=\left[\begin{array}{cc}
14.569 & 6.592 \\
6.592 & 5.191
\end{array}\right] \text {. }
$$

The contribution to the labour force is considered within an uncertainty ellipse. Therefore, the length of the axes, describing the forcefulness of young men and women, should be obtained. The eigenvalues $\left(\lambda_{1}, \lambda_{2}\right)$ can be calculated by (Shoaib, 2017)

$$
\begin{aligned}
& \lambda_{1}=\frac{\sigma_{r}+\sigma_{i}+\sqrt{\left(\sigma_{r}-\sigma_{i}\right)^{2}+4 \sigma_{r i}^{2}}}{2}, \\
& \lambda_{2}=\frac{\sigma_{r}+\sigma_{i}-\sqrt{\left(\sigma_{r}-\sigma_{i}\right)^{2}+4 \sigma_{r i}^{2}}}{2} .
\end{aligned}
$$

The eigenvalues corresponding to the axes have been provided as 17.97, 1.79, respectively. The lengths of the major and minor axes of the ellipse in Figure 2 are directly proportional to the square root of the eigenvalues:

$$
a=\sqrt{\lambda_{1}}=4.239, b=\sqrt{\lambda_{2}}=1.338 .
$$

In measurement uncertainty approach, instead of the direct values of $a$ and $b$, an expanding with a constant $k$ (coverage factor) taken from the statistical distribution is used. Coverage probability can be considered as a performance measure of the analysis. This level of confidence creates a statement including the measurand. In the case of the complex measurand, the effective number of degrees of freedom associated with the uncertainty has been defined and for $95 \%$ confidence level the coverage factor has been calculated as $k=\sqrt{\chi_{0.95}^{2}}=2.448$. Thus, the length of the axes depicted in Figure 2 has been provided as follows

$$
\begin{aligned}
& L_{1}=k a=2.448 \times 4.239=10.377, \\
& L_{2}=k b=2.448 x 1.338=3.276 .
\end{aligned}
$$

The measurement data ellipse constructed by observation data (Marjanovic, 2016) and uncertainty region (95\% confidence level) described the contributions that are illustrated in Figures 5 and 6 . Both the outputs reveal the outlier sectors such as wholesale, manufacturing, agriculture and forestry. It should be noted that employed youths in these sectors provide major contributions comparing with the others.

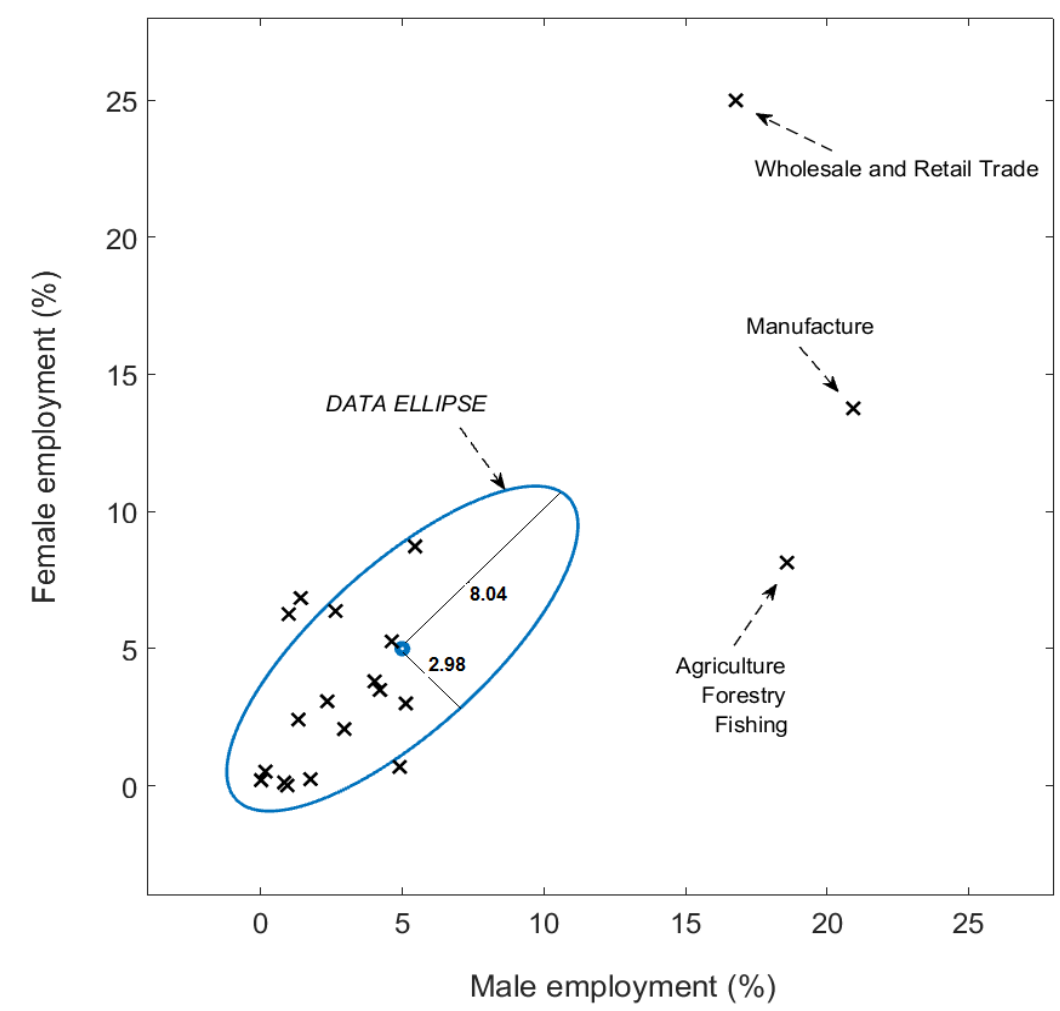

Figure 5: Data ellipse for youth employment 


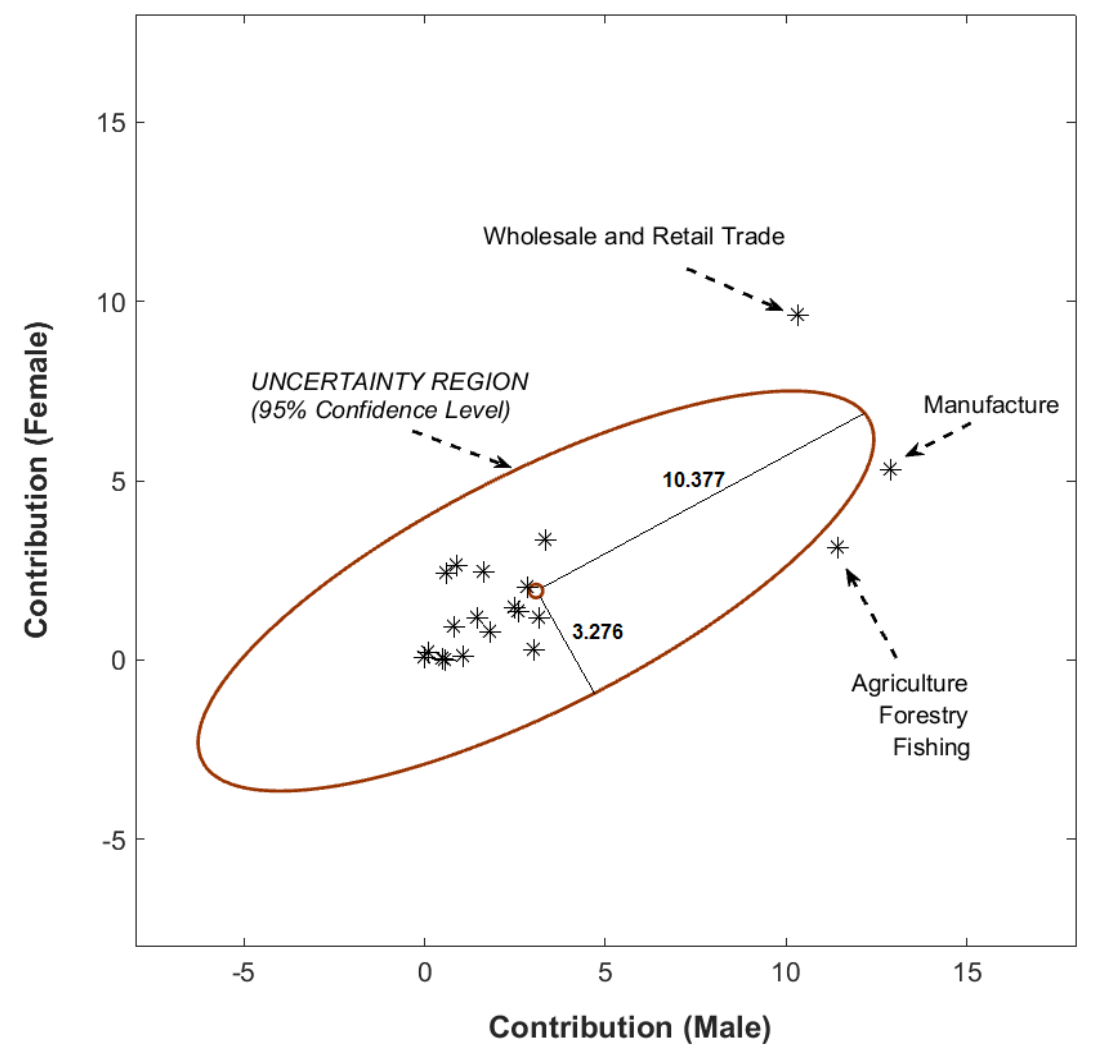

Figure 6: Uncertainty region for contributions of genders

In a polar form,

$$
\theta=\arctan \frac{C_{m_{\text {ave }}}}{C_{f_{\text {ave }}}}=\arctan \left(\frac{3.077}{1.923}\right)=58 .
$$

In Eq. (16), the angle $\theta$ is positive in the counter clockwise sense. With a similar data, the absolute value of magnitude of $Z|z|$ is provided by

$$
|z|=p=\sqrt{1.923^{2}+3.077^{2}}=3.63 .
$$

One of the important steps is revealing the positions of the gender contributions on the uncertainty ellipse. For this purpose, the rotation angle $(\Phi)$ illustrated in Figure 2 has been calculated as follows (Shoaib, 2017):

$$
\Phi=\frac{1}{2} \arctan \left(-\frac{2 \sigma_{r i}}{\sigma_{r}-\sigma_{i}}\right)=-0.476 \mathrm{rad} .
$$

\section{Discussion}

To make a reliable assessment, it is required to provide a two-dimensional region of uncertainty in the complex plane. For this purpose, the uncertainty matrix-based elliptical region in the complex plane has been created. The summary of the results is illustrated in Figure 6 where the gender vector denotes the part of the complex number in the ellipse. The absolute value of the rotation angle $(\Phi)$ has been calculated by a conversion: $0.476 \mathrm{rad}=27.2$ degree.

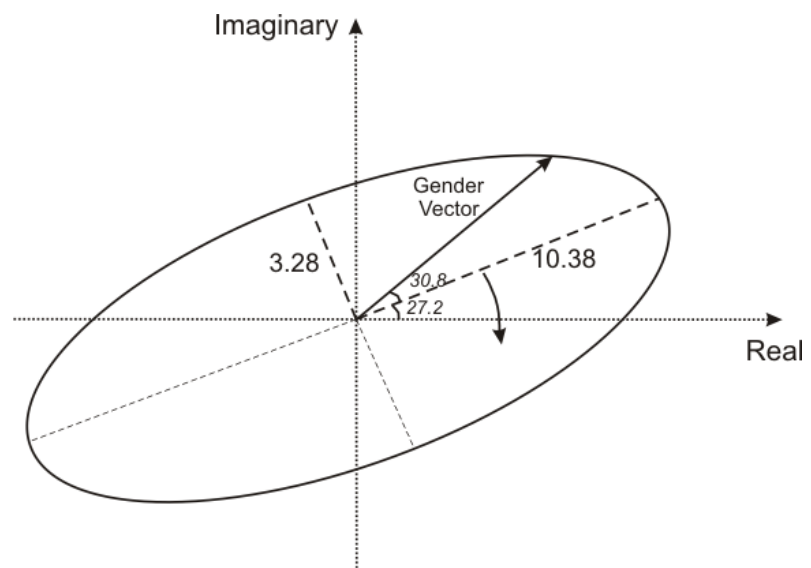

Figure 7: Phase diagram for gender contributions 
From a geometrical framework, the analysis has been conducted on positive $x$-axis and the rotation angle (counter clockwise) controls the position of ellipse and its normality. The main purpose of the employment is providing a balance between the genders. To do this, a trend from imaginary part to real part (bigger $\theta$ ) is required. The negative rotation angle obtained from the analyses reveals this trend which corresponds to "imaginary reflection" in mathematics. Beyond the mathematical analyses, the reflection of imaginary part with opposite trend (clockwise) can be suggested from a social science framework.

In conjunction with the complex number structure, the uncertainty ellipse given in Figure 4 can also be handled as a phase diagram. From this perspective, both rotation angle $(\Phi)$ and maximum contributions (strengths) of the genders come into prominence. The maximum strengths for the genders Male $(M)$ and female $(F)$ illustrated in Figure 7 have been provided based on modifying the expression given in Yang and Parkhurst (2015):

$$
\begin{aligned}
& \mathrm{M}_{\text {max }}=\sqrt{\left(L_{1}^{2} \cos ^{2} \theta+L_{2}^{2} \sin ^{2} \theta\right)}=9.349,(19) \\
& \mathrm{M}_{\text {max }}=\sqrt{\left(L_{1}^{2} \sin ^{2} \theta+L_{2}^{2} \cos ^{2} \theta\right)}=5.567 .(20)
\end{aligned}
$$

It should be noted that, the formulas of Yang and Parkhurst (2015) are for an ellipse centred at the origin. Therefore, it is necessary to add $C_{m_{\text {ave }}}=3.077$ to $M_{\max }$ and $C_{f_{\text {ave }}}=1.923$ to $F_{\max }$, respectively. The corresponding points on the ellipse are indicated in Figure 8, showing that the computations are correct.

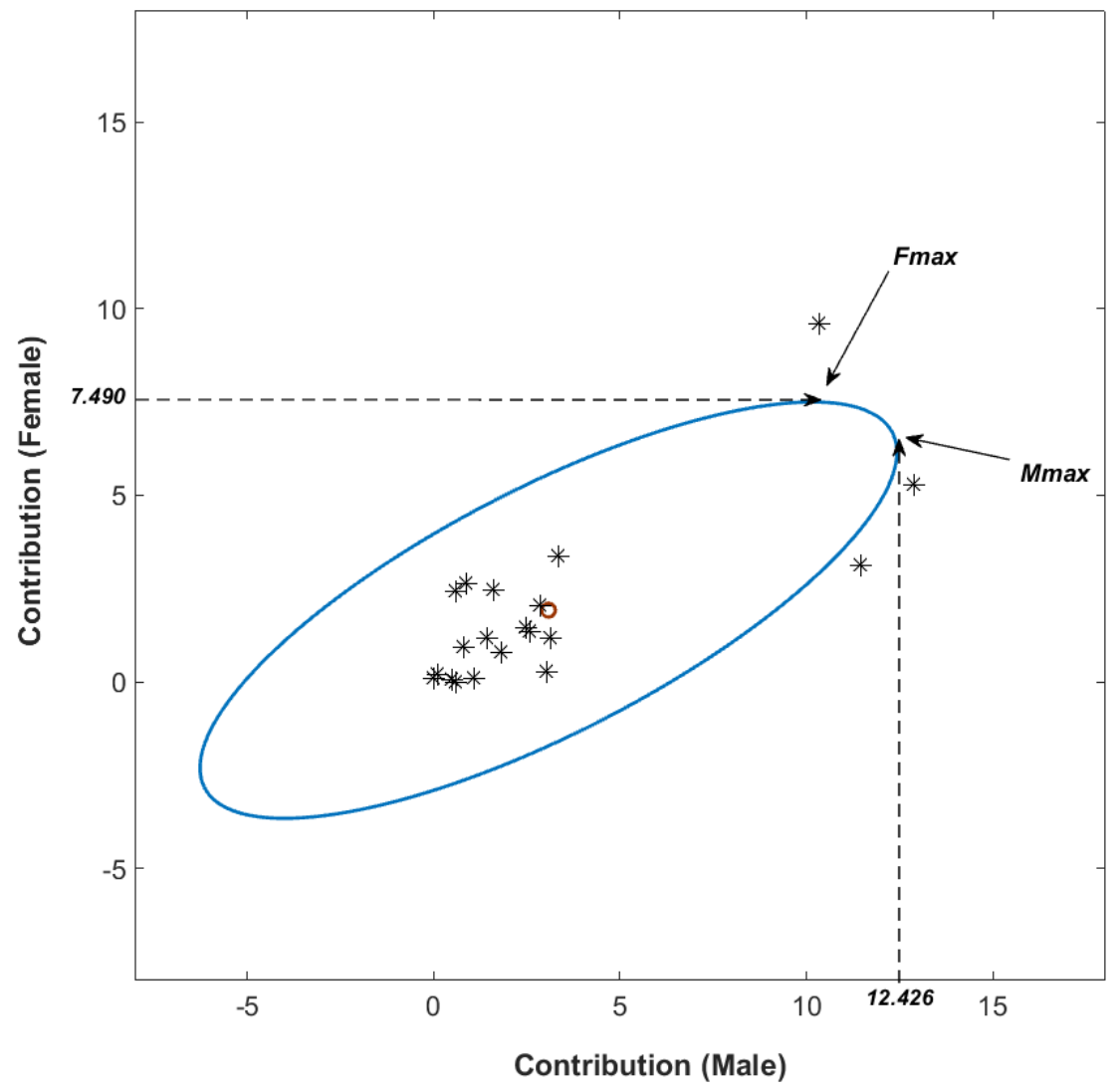

Figure 8: Uncertainty ellipse with maximum contributions

The shape of the ellipse depends on the involvement of men and women in the labour force. The role of an uncertainty region (in the plane) is to provide a $95 \%$ confidence that the true mean (i.e. the mean of the records) corresponds to a point in that region or, if we prefer, that the probability that the mean lies outside that region is only $5 \%$. The contributions in extreme cases corresponding to $M_{\max }$ and $F_{\max }$ can be provided as follows: 


$$
\begin{aligned}
& C_{m}=\frac{12.426}{12.426+7.490} x 100=62.4(\%), \\
& C_{f}=\frac{7.490}{12.426+7.490} x 100=37.6(\%)
\end{aligned}
$$

Before the uncertainty analysis, the average observations calculated from direct statistics (Marjanovic, 2016) via Eq (10) were as 61.6 and 38.4, respectively. The uncertainty-based evaluation considered not only observational values but also statistical dependencies (variance and covariance) and finally produced more reliable results using limited number of records (20 sectors). The point determined by Eqs. (18) and (19) is not in confidence region due to decreasing female contribution. This may address a potential problem.

To clarify the effect of the rotation angle $(\Phi)$ on the gender roles, a series of calculations have been performed using Eqs. (19) and (20). Table 1 summarizes the results. Even though the $(\Phi)$ can take positive or negative sign, the women's contribution in employment increases with the angle.

Table 1: Importance of rotation angle on work

\begin{tabular}{|c|c|c|}
\multicolumn{3}{c}{ forces } \\
\hline Rotation Angle & Max (male) & Max (female) \\
\hline 0 & 10.377 & 3.276 \\
\hline 27.2 & 9.349 & 5.567 \\
\hline 45 & 7.683 & 7.683 \\
\hline 75 & 4.109 & 10.059 \\
\hline 90 & 3.276 & 10.377 \\
\hline
\end{tabular}

From a labour economics perspective, youth unemployment is a serious challenge that Serbia is facing. The youth employment rate in Serbia in 2015 was only slightly higher than $30 \%$, which is about 15 percentage points less compared to the EU countries. The male employment rate is significantly higher than the female employment rate: $38 \%$ versus $25 \%$ (Arijas, 2018). Another fact is that women are primarily employed in the lower paying service sector jobs.

As inspected by the complex-valued uncertainty analysis, the real situation is more devastating than thought. Therefore, to avert getting bigger and to provide an increase of female contribution to labour force, new employment policies should be prioritized.

\section{CONCLUSIONS}

The determination of the relative contributions of young women and young men to the youth Serbian labour market has been investigated. For this purpose, first the youth employment is considered as a complex number used in mathematics. A covariance-matrix-based uncertainty analysis has been conducted and the parameters have been appraised. Along with the real component (young men), the contribution of young women is treated as the imaginary component. By using the data derived from 20 different domains, the problem is stated as a complex value problem and a measurement uncertainty analysis framework is utilized.

The outcomes of the study have been illustrated by an uncertainty confidence ellipse at $95 \%$ confidence level. The ellipse included dependencies and alternatives. The phase diagrams reveal that the contribution of the young women in Serbia to general employment needs managerial actions on the ground of critical steps by strengths and angles. Thus, making an appraisal on a social problem via engineering tools can create a synergy and interesting results.

\section{ACKNOWLEDGEMENT}

The authors extend their appreciation to Professor Branka Jankovic (Preschool Teaching College, Novi Sad) and Professor Milan Nikolic (University of Novi Sad, Technical Faculty "Mihajlo Pupin", Zrenjanin) for stimulating discussions.

\section{REFERENCES}

Andreescu, T., \& Andrica, D. (2014). Complex numbers from A to...Z. New York: Birkhauser.

Ara, S. (2019). Globalisation and gender inequality: evidence from labour market in India. Journal of Quantitative Economics, 17(1), 93-120.

Arijas, DJ. (2018). Periodic evaluation of the local youth employment initiative programmes, Social Inclusion and Poverty Reduction Unit, Belgrade: Government of Republic of Serbia.

Boll, C., Leppin, J., Rossen, A., \& Wolf, A. (2016). Magnitude and impact factors of the gender pay gap in EU countries, European Commission.

Cerciello, M., Agovino, M., \& Garofalo, A. (2019). The caring hand that cripples? The effects of the European regional policyon local labour market participation in Southern Italy, Socio-Economic Planning Science, 68, 100703. https://doi.org/10.1016/j.seps.2019.03.00 (in press) 
Ćoćkalo, D., Đorđević, D., Nikolić, M., Stanisavljev, S., $\&$ Terek, E. (2017). Analysis of possibilities for improving entrepreneurial behaviour of young people - research results in Central Banat district. Journal of Engineering Management and Competitiveness (JEMC), 7(2), 97-108.

Collet, R., \& Legros, D. (2016). Dynamics of female labour force participation in France. Applied Economics, 48(30), 2807-2821. DOI: 10.1080/00036846.2015.1130787.

Dokmanovic, M. (2016). Gender analysis for Serbia, EU IBF Report.

Garelli, M. \& Ferro, A. (2012) A unified approach for S-parameter uncertainty evaluation. IEEE T. Microwave Theory, 60(12): 3844-3855.

Gevrek, Z.E., \& Seiberlich, R.R. (2011). Semiparametric decomposition of the gender achievement gap: An application for Turkey. Labour Economics, 31, 27-44.

Hall, B. (2008). Using uncertain complex numbers with VNA measurements, 71st ARFTG Microwave Measurement Conference, Atlanta.

Hall, B. (2012). Notes on complex measurement uncertainty - part 2, Industrial Research Report. Measurement Standards Laboratory of NZ, 2557, 143.

Hall, B. (2013). Expanded uncertainty regions for complex quantities. Metrologia, 50, 490-498.

Hall, B. (2016). Evaluating the measurement uncertainty of complex quantities: a selective review, Metrologia, 53, 25-31.

JCGM. (2008). Evaluation of measurement dataGuide to the expression of uncertainty in measurement, BIPM, Paris.

Kreyszig, E. (2011). Advanced engineering mathematics, Wiley.

Kumar, A. (2006). Nonparametric conditional density estimation of labour force participation. Applied Economics Letters, 13, 835-841.

Lewandowski, A., Williams, DW. \& Hale, PD. (2010). Covariance-based vector-network-analyzer uncertainty analysis for time- and frequency-domain measurements, IEEE Trans. Microwave Theory Tech., 58(7), 1877-1886.

Marjanovic, D. (2016). Labour Market Transitions of Young Women and Men in the Republic of Serbia, Youth Employment Programme. ILO.

Martins, MFO. (2001). Parametric and semiparametric estimation of the sample selection model: an empirical application to the female labour force, Journal of Applied Econometrics, 16, 23-39.

Matsumo, M. \& Elder, S. (2010). Characterizing the school-to-work transitions of young men and women: Evidence from the ILO school-to-work transition surveys, Employment Working Paper No.51, Geneva: ILO.

Ostojić, I. \& Petrović, P. (2018). Entrepreneurship in Serbia, Proceedings of the scientific conference of the Center for Economic Research of the Institute of Social Sciences in Belgrade, Entrepreneurship vs. Renting, Institute of Social Sciences, Center for Economic Research, 262-269 (in Serbian).

Paunović, G. (2017). The role of small and mediumsized enterprises and entrepreneurship in the development of national economy. Economics: Theory and Practice, 10(1), 44-63.

Perez, D.A. \& Zangl, H. (2019). Introducing uncertainty of complex-valued quantities in measurement science education. In Photonics and Education in Measurement Science, ed.Rosenberger et al.,Proc. Of SPIE 1114410. Jena, Germany. Doi: 10.1117/12.2531840.

Petrovic, N., Terek, E., Sajfert, D., Jovanovic, Z., \& Petkovic, T. (2019). Job satisfaction and relations with the leader on an example of a domestic company. Journal of Engineering Management and Competitiveness (JEMC), 9(2), 113-123.

Possolo, A. (2015). Simple guide for evaluating and expressing the uncertainty of NIST measurement results, Washington: NIST Technical Note 1900

Ridler, N.M., \& Salter, M.J. (2014). Evaluating and expressing uncertainty in high-frequency electromagnetic measurements: a selective review. Metrologia, 51, 191-198.

RSME. (2015). SME Development strategy \& action plan 2015-2020. Belgrade: The Republic of Serbia The Ministry of Economy.

Shoaib, N. (2017). Vector network analyzer (VNA) measurements and uncertainty assessment, Springer, Switzerland.

Tutmez, B, Terek, E., Nikolic, M., \& Jankovic, B. (2019). Handling work force participation in Serbia by new perspective, EMC2019, Zrenjanin, Serbia.

Yang, F., \& Parkhurst, A.M. (2015). Efficient estimation of elliptical hysteresis with application to the characterization of heat stress. Journal of Agricultural, Biological, and Environmental Statistics, 20(3), 371-388 


\section{STATISTIČKO UČENJE BAZIRANO NA KOMPLEKSNIM VREDNOSTIMA ZA ISTRAŽIVANJE UČEŠĆA RADNE SNAGE MLADIH U SRBIJI}

Zapošljavanje mladih ima presudan značaj u socio -ekonomskom planiranju . Očekuje se da upotreba dinamične i sposobne radne snage može povećati kvalitet industrijskih proizvoda i takođe je potrebno za jačanje ekonomije. Što je još važnije, doprinos radnoj snazi je od presudnog značaja za javno blagostanje . U ovoj fazi , budući da se uloga mlade žene u ukupnoj radnoj snazi ne razmatra dovoljno, ovo istraživanje se fokusira na utvrđivanje relativnog efekta ženske radne snage. U tu svrhu, prvo se zapošljavanje mladih smatra složenim konceptom; zajedno sa stvarnom komponentom (mladići), doprinos mladih žena tretira se kao imaginarna komponenta. Primenom podataka dobijenih iz 20 različitih domena (sektora), problem se navodi kao složen problem vrednosti i koristi se za analizu merene nesigurnosti. Merna nesigurnost kompleksne veličine (zaposlenosti) izražava se regionom u složenoj ravni. Konačno se stvara elipsa pouzdanosti od $95 \%$ nivoa pouzdanosti. Fazni dijagrami dobijeni statističkim učenjem pružili su neke abnormalnosti a takođe i potencijale.

Ključne reči: Radna snaga; Kompleksni broj; Zaposlenost mladih; Merene nesigurnosti. 